\title{
Öğretmen Adayları Perspektifinden Yaşam Boyu Öğrenme, Dünya Vatandaşlığı ve Eleştirel Düşünme Arasındaki İlişsiler
}

\section{The Relationship between Lifelong Learning, World Citizenship and Critical Thinking from the Perspective of Teacher Candidates}

\author{
Derya GÖĞEBAKAN YILDIZ ${ }^{1}$, Semiha ŞAHIN ${ }^{2}$, Mustafa ŞAHIN ${ }^{3}$
}

\begin{abstract}
I Sorumlu Yazar, Doç.Dr., Eğitim Bilimleri Bölümü, Demirci Eğitim Fakültesi, Celal Bayar Üniversitesi,Türkiye,derya.yildiz@cbu.edu.tr, (https://orcid.org./0000-0002-8831-8878)
\end{abstract}

2 Doç.Dr., Eğitim Yönetimi ABD, Buca Eğitim Fakültesi, Dokuz Eylül Üniversitesi, Türkiye, semiha.sahin@deu.edu.tr, (https://orcid.org./0000-0002-1135-0327)

I Prof.Dr., Sosyal Bilgiler Eğitimi ABD, Buca Eğitim Fakültesi, Dokuz Eylül Üniversitesi, Türkiye,mustafa.sahin@deu.edu.tr, (https://orcid.org./0000-0001-8789-514X)

Geliş Tarihi: 25.09.2021

Kabul Tarihi: 17.12.2021

ÖZ

$\mathrm{Bu}$ çalışmada, öğretmen adaylarının, eleştirel düşünme ve yaşam boyu öğrenme eğilimleriyle dünya vatandaşlığı yeterlik algıları arasındaki ilişkiler incelenmiştir. Araştırmaya iki devlet üniversitesinde açılan pedagojik formasyon derslerine devam eden 508 öğretmen adayı katılmıştır. Veri toplama aracı olarak "Kaliforniya Eleştirel Algı Ölçeği, "Yaşam Boyu Öğrenme Eğilimleri Ölçeği”, "Dünya Vatandaşlı̆̆ Alg1 Ölçeği”" kullanılmıştır. Bu çalışmada, öğretmen adaylarının, eleştirel düşünme ve yaşam boyu öğrenme eğilimleriyle dünya vatandaşlığı yeterlik algıları arasındaki yapısal ilişkileri incelemek amacıyla çok faktörlü yordayıcı korelasyonel desen kullanılmıştır. Bu amaçla doğrulayıcı faktör analizi, betimsel istatistikler ve korelasyon istatistikleri kullanılmıştır. Araştırma sonucunda eleştirel düşünme, yaşam boyu öğrenme ve dünya vatandaşlığı arasında orta ve düşük düzeyde anlamlı ilişkiler saptanmıştır. Araştırmanın nihai sonucuna göre öğretmen adaylarının görüşleri doğrultusunda yaşamboyu öğrenme eğilimleri ve dünya vatandaşlığı algısının eleştirel düşünme eğilimlerine etkisi ortaya koyulmuştur.

Anahtar Kelimeler: Eleştirel düşünme, yaşam boyu öğrenme, dünya vatandaşlığı, öğretmen adayları.

\begin{abstract}
In this study, the relationships between teacher candidates' critical thinking and lifelong learning dispositions and global citizenship competency perceptions were examined. 508 teacher candidates attending pedagogical formation courses in two state universities participated in the research. "California Critical Thinking Disposition Scale", "Lifelong Learning Tendency Scale" and "Global Citizenship Competency Perception Scale" were used as data collection tools. In this study, a multi-factor predictive correlational design was used to examine the structural relationships between preservice teachers' critical thinking and lifelong learning dispositions and their perceptions of global citizenship competency. For this purpose, confirmatory factor analysis, descriptive statistics and correlation statistics were used. As a result of the research, moderate and low level significant relationships were found between critical thinking, lifelong learning and global citizenship. According to the final result of the research, the effects of lifelong learning tendencies and global citizenship perception on critical thinking dispositions were revealed in line with the views of teacher candidates.
\end{abstract}

Keywords: Critical thinking, lifelong learning, global citizenship, teacher candidates. 


\section{GIRIŞ}

Bir toplumun var olması, varllğgın koruması ve gelişmesinde eleştirel düşünen etkin bireylerin çok sayıda olması önemli bir toplumsal özelliktir ve bu son on yılların önde gelen konuları arasında yer almaktadır. Eleştirel düşünmenin karar verme ve bilimsellikle olan ilişkisinin bireyleri araştırma ve bilgiye sevk etmesi her yaştaki bireylerin öğrenmeye olan ilgisini artırmaktadır. Bir başka deyişle eleştirel düşünme etkinliği için yaşam boyu öğrenme kaçınılmazdır. Eleştirel düşünme ve yaşam boyu öğrenme küresel dünyanın gerekliliği olarak ortaya koyulan dünya vatandaşı bireyin genel özellikleri arasında anılmaktadır. Mart 2020'de ortaya çıkan Covid-19 dünya vatandaşlığının önemini ortaya koyan tipik bir örnektir. Farklı ülkelerde farklı kültürel ekonomik sosyal özelliklerden gelen bireylerin tüm insanlığı etkileyen böylesi küresel bir sorunu birlikte deneyimlemeleri ve çözüme kavuşturulabilme çabaları dünya vatandaşlığı olgusunu bir adım daha bir öne çıkarmaktadır. Bu bağlamda eleştirel düşünme, yaşamboyu öğrenme ve dünya vatandaşlığı kavramlarının birbirleriyle olan ilişkileri dikkat çekmektedir.

Eleştirel düşünme (ED) üst düzey karar verme becerisidir (Goryunova, Jenkins, 2017) Ölçüt ve standartlarıyla bilimsel yöntem ve karar verme benzeşmektedir, ikisi de problem çözümünde gerekli süreçlerdir. Lipman (1988) ise ED'yi akıl yürütme, tahmin, değerlendirme, tercih, gruplama, sınıflama, mantıklı çıkarsama ve varsayım geliştirme kavramalarına yükleme yaparak tanımlamıştır. Yazara göre niteliksiz, şansa dayalı ve yapılandırılmamış düşüncelerden uzak durarak ED’yi kullanmak gerekir.

Dünya vatandaşlığı ise dünyadaki işleyiş ve sorunlara ilişkin küresel farkındalık ve irade gösterme için "öz-yeterlik" algısının gelişmiş olmasını ve aktif sivil katılımı ifade eder (Kronfli, (2011). Oxfam'a göre, dünya vatandaşı kimliği olan kişiler, dünyanın küçülmesi, "adalet, eşitlik ve farklılıklara saygı" gibi konularda birikimli olmal1; "eleştirel düşünme, etkili tartışma, işbirliği ve sorun çözme, empati, öz saygı ve sosyal adalet gibi yetilere sahip olmalıdır (Kan, 2009b).

"Yaşam boyu öğrenme (YBÖ) bireylerin daha çok örgün eğitimden sonra ve yaşam boyunca deneyimledikleri bilgi ve becerilerin sürekli gelişimidir" (Encarta Dictinoarry, 2008 akt. Lonra, 2011). Burada öğrenme değişimle ilgilidir ve değişim öğrenmeyi yönlendirici bir özellik taşır. Değişim ve öğrenme hayat boyunca meydana gelir ve yeni beceriler kazanmayı sağlar. Uyumlanma, değişim ve gelişimin anahtar kelimesi durumundadır. $\mathrm{Bu}$ bakımdan yaşam kalitesiyle de bağlantılıdır. Yaşam boyu veya sürekli öğrenme genellikle yetişkin veya sürekli eğitim alanı olarak görülür (Lonra, 2011).

Eleştirel düşünme, dünya vatandaşlığı ve yaşam boyu öğrenmeyle ilgili yapılan çalışmalar incelendiğinde oldukça zengin bir literatüre ulaşılmaktadır. Örneğin, Anıl ve Eranıl (2017) ve Ricketts (2005) eleştirel düşünme ile ED ilişkisini, Türnüklü ve Yeşildere (2005) öğretmen adaylarının eleştirel düşünme özelliklerini belirlemişler; Çokluk Bökeoğlu ve Yılmaz (2005) "üniversite öğrencilerinin eleştirel düşünmeye yönelik tutumları ile araştırma kaygıları arasındaki ilişkiyi" ve Akbıyık ve Seferoğlu (2006) "eleştirel düşünme ile akademik başarı arasındaki ilişkiyi” ve Bayat (2014) "öğretmen adaylarının eleştirel düşünme düzeyleri ile akademik yazma başarıları arasında ilişkiyi” incelemişlerdir. Ayrıca okul öncesi (Ocak, Eymir ve Ocak, 2016) ve Türkçe eğitimi öğretmen adaylarının eleştirel düşünme düzeyleri bazı değişkenler açısından ele alınmıştır (Çetinkaya, 2011; Dutoğlu ve Tuncel, 2008; Ekinci, 2009; Şen, 2009).

Dünya vatandaşlığı ile ilgili alanyazın incelendiğinde; dünya vatandaşlı̆̆ına ilişkin ölçek geliştirme ve uyarlama (Şahin, Şahin, Göğebakan Yıldız, 2016; Karışan, ve Yılmaz Tüzün, 2017) ögretmen adaylarının dünya vatandaşlık becerilerini geliştirmeye yönelik eğitim programlarının geliştirilmesi (Göğebakan Yıldız, 2018), dünya vatandaşı öğretmenleri yetiştiren programların özellikleri (Bates, 2008; Mclean, Cook ve Crowe, 2008; Şahin, Şahin ve Göğebakan Yıldız, 2016) öğretmen adaylarının dünya vatandaşlığına yönelik görüşleri ve farklı demografik değişkenlerle olan ilişkisi (Ebbeck, 2006; Kaya ve Kaya, 2012; Mclean, Cook ve Crowe, 2008), dünya 
vatandaşlı̆̆ının eleştirel düşünme (Kaya ve Sarıçam, 2016) ve YBÖ (Holvoet, Lombaerts, Engels, Backer, Vanwing, 2010) eğilimleri arasındaki ilişkileri ortaya koyan çalışmalara yer verildiği görülmektedir.

Yaşam boyu öğrenme araştırmaları ise daha çok öğretmenlerle yapılmıştır (Coşkun, ve Demirel, 2012; Demirel ve Akkoyunlu, 2010; Evin Gencel, 2013; Gencel, 2013; İzci ve Koç 2012; Jenkins, 2004; Selvi, 2011; Şahin, Akbaşlı ve Yanpar Yelken, 2010; Yaman, ve Yazar, 2015). Coşkun (2009) ise öğretmen adaylarını bireysel özelliklerine göre YBÖ’yü incelemişlerdir. Araştırmalar incelendiğinde bu değişkenler bireysel ya da başka bazı değişkenlerle incelense de bu üç değişkenin her biri arasındaki ilişkiyi ve ilişkilerin yapısal modelini ele alan bir araştırmaya rastlanmadığından bu araştırma özgündür ve sonuçları uygulama ve araştırmacılara ışı tutabilecektir. Araştırmanın amacı bu üç değişken arasındaki ilişkiyi incelerken YBÖ ve dünya vatandaşlığının ED’yi yordama durumunu incelemektir.

\subsection{Yaşam Boyu Öğrenme}

Günümüzde daha sistematik olan bilgi, teknoloji ve bunlara bağlı olarak sosyal, iş ve günlük rutinler değişiklik göstermekte, bilgi ve teknoloji sürekli yenilenmekte ve her durum kendi bağlamında kendini güncellemektedir. Bu durumda toplumların ve bireylerin bu duruma uyum sağlaması ve kendilerini yenilemeleri büyük önem taşımaktadır. Bu yenilik ve güncellemelere günlük hayatta ve iş yaşamında yetişmenin en işlevsel yolu eğitimden geçmektedir. Belirli sürede ve daha çok 18-20 yaş aralığında tamamlanan ilkokuldan üniversiteye kadar süren temel eğitim süreçlerinin bu gelişmeleri tek başına karşılayabilmesi beklenemez. Kaldı ki her şeyi resmi süreçli okullardan elde etmek mümkün değildir.

Öğrenme deneyimlerinin önemli bir bölümü okul dışına taşan yapılanmış veya yapılanmamış doğal ortamlarda gerçekleşmektedir. YBÖ ihtiyacı ve kritik rol burada ortaya çıkmaktadır. YBÖ örgün eğitim sürecinde olan veya olmayan bireylerin gönüllü ve istekli olarak bilgi ve becerini geliştirmeyi amaçlar. YBÖ üç şekilde gerçekleşir. Bunlardan biri doğal ya da informal diye adlandırılan kendiliğinden eğitimdir. İkincisi Bolhuis'in (2003) de belirttiği gibi kişinin kendi yönlendirdiği öğrenme biçimidir. Üçüncüsü ise bireyler kendini geliştirmek, meslek edinmek, boş zaman geçirmek ve hobi edinmek gibi daha bir çok konuda planlı olarak düzenlenen sertifikalı yaygın eğitim kurslarıdır. Bunlar halk eğitim gibi kamu kuruluşları tarafından ya da özel kuruluşlarca düzenlenen eğitim programlarıdır. Günümüzde internet özellikle ilk iki grup için büyük bir kaynaktır. Ülkemizde en yapılanmış ve sürekliliği olan yaşam boyu öğrenme etkinlikleri, Milli Eğitim Bakanlığı tarafında düzenlenen halk eğitim kurslarıdır. Ayrıca özel sektör tarafından açılan kurslar da bakanlık tarafından denetlenmektedir. İş yerlerindeki hizmetiçi eğitim kursları da bu gruba girer. Dünya vatandaşlığıyla bağlantılı en önemli yaşam boyu ögrenme etkinlikleri dil kurslarıdır denebilir.

Yine uluslararası önemi bakımından YBÖ, UNESCO ve OECD gibi ulusal ve çok uluslu işletmelerin, eğitimcilerin ve uluslararası kuruluşların modern toplumun talebi olarak görüş birliği içinde olunan "Yaşam Boyu Öğrenme Dünya Girişimi”" olarak tanımlanmıştır (Stewart, Ball, 1995 akt. Bolhuis, 2003). AB tarafından 1996 yılı “Avrupa Yaşam Boyu Öğrenme Yılı” olarak ilan edilmiştir. 2000'lerden sonra AB üyesi ülkeler YBÖ çalışmalarını raporlaştırmışlar 2000'de Lizbon ve 2001'de Stockholm'de yapılan konsey toplantılarında YBÖ gündeme gelmiştir. YBÖ için "beşikten mezara kadar" eğitim vurgusu yapılmıştır. 1999 yılında Bologna Üniversitesi’nde yirmidokuz Avrupa ülkesinin eğitim bakanları ortak bildiri yayımlamış, 2003'de Berlin Konferansı'nda üniversiteler "öğrenci merkezli ve esnek öğrenme" ortamları için sorumlu tutulmuşlardır. Böylece birçok üniversite programlarını yetişkinleri de kapsayacak şekilde genişletmiş, "kredili ve kredisiz programlar, yetişkin ve sürekli eğitim birimleri, mesleki uzmanlık öğrenim okulları, uzaktan öğrenim birimleri” etkinleştirilmiştir (Evin Gencel, 2013; Toprak ve Erdoğan, 2012).

YBÖ örgün eğitime girmiş veya girmemiş çocuk, genç ya da yetişkinlerin eğitimini, sürekli mesleki gelişmeyi ifade eden bireylerin bütün yaşamı süresince ihtiyaç duyduğu öğrenme 
faliyetleridir. YBÖ günümüzde önemli bir iş ve görevdir. Ayrıca gerekli beceri, bilgi ve anlayışın güncellenmesi için kişisel olarak sürekli gelişmeyi ifade eder (Stenfors Hayes vd., 2008). YBÖ birey yaşamının tamamını içeren "öğrenme süreci" veya hayat tecrübesini içeren deneyimsel öğrenmeyi kapsar (Field ve Leicester, 2003) ve her zaman "öğrenme toplumu” gibi öğelerle yakından ilgilidir. Knapper ve Cropley'in (2007) belirttikleri gibi, YBÖ mevcut eğitimdeki eksikleri karşılamak için "alternatif ve esnek bir öğrenme yaklaşımıdır". Günümüzde ise giderek artan bir formal-yasal öğrenme sürecinden daha önemli bir ihtiyaca dönüşmüştür. Bu bakımdan kişinin kendiliğinden yönettiği öğrenme, resmi olandan daha etkili hale gelmektedir (Field, Leicester, 2003; Stenfors Hayes vd., 2008).

YBÖ’nün insanlara hızla değişen dünyada gelişmelere uyumu kolaylaştıracak tutumları, beceri, bilgi ve donanım kazandırmak için hayati bir rolü vardır. Öğrenenlerin taleplerine cevap vermek için, YBÖ uygulayıcıları, topluluk çalışanları ve sendikalar, küreselleşme, sürdürülebilir kalkınma, eşitlik ve çeşitlilik gibi sorunlara eğitsel çözümler geliştirmekte, dünyanın birbirine bağlı bir bütün olarak algılanmasını ve küresel boyutun aktif olarak anlaşılmasını desteklemektedir (Cyfanfayt, 2008). Varsayım mümkün olan en yüksek eğitimin en iyisine ulaşmaktır. $\mathrm{Bu}$, ancak yeterli sayıda insan yeni bilgiler yaratabildiğinde ve başkaları da en azından bilgideki bir değişikliğin yol açtığı değişiklikleri yakalayabildiğinde etkilidir (Bolhuis, 2003).

Yaşamda öğrenme isteği genellikle karışıklık, problemler, yeterli beceri ve bilgi eksikliğinden tedirgin ve rahatsız olmak sonucunda ortaya çıkar (Joyce vd., 1992 akt. Bolhuis, 2003). Öğrenme değişim ve değişimin riskleriyle ilişkilidir ve bu nedenle cesaret ister (Bolhuis, 2001 akt. Bolhuis, 2003). Bir başka değişle öğrenme kişide ve hayatında değişime neden olurken, toplumsal, ekonomik ve teknolojik değişimler kişilerin kendilerini gelişmelere göre yenilemesini ve günün teknik ve yaşamsal becerilerine sahip olmalarını gerektirir. Bu gibi yaşamsal becerilere sahip olma kişinin hele de günümüzde çı̆̆ gibi büyüyen teknolojik değişmeler karşısında son derece önem kazanmaktadır.

Toplumsal yaşam ve iletişimin de buna göre yeni şekiller aldığ günümüzde bu gibi öğrenmelerden yeterince yararlanılamadığında kişinin sosyalleşmesi ve mutluluğuna olumsuz yansıyabilir. Ayrıca YBÖ işte verimlilik, ekonomik gelişmeler ve sürdürülebilir kalkınma açısından önem taşmaktadır. Araştırma sonuçları, öğretmenlerin yaşam boyu öğrenme becerilerinin kendi öğrenmelerini yönetme becerileri, bilgi arama ve bilgiye erişme yeteneği, eleştirel düşünme becerileri, iletişim becerileri, kişilerarası beceriler, problem çözme becerileri, proje planlama yeteneği, alternatifleri değerlendirme becerisi, takım hâlinde çalışabilme, meslektaşları ve öğrencileri ile birlikte çalışma becerileri olduğunu göstermiştir (Selvi, 2011).

\subsection{Dünya Vatandaşlığı}

Aydınlanma felsefesi ve Fransız devrimi süreciyle birlikte yeniden şekillenmeye başlayan vatandaşlık kavramı bir devlete uyruğu nedeniyle bağlılıktan öte temel insan hakları talepleriyle birlikte anılmaya başlanmıştır (Pike, 2008). Modernizmden postmodernizme geçiş, küreselleşme, göç olgusu, teknolojik gelişmeler, insan hakları alanındaki göreli gelişmeler birçok kavram gibi vatandaşlık kavramını da değişikliğe uğratmış ve dünya vatandaşlığı kavramını gündeme taşımıştır. Bu yeni vatandaşlık tanımında tüm insanlığa karşı sorumluluk, evrensel bilinç ve duyarlılık daha fazla vurgulanmaya başlanmıştır (Hicks, Holden, 2007; Silva, 2014).

Okul öncesi eğitimden yetișkin eğitimine kadar öğrenenlerin 21. yüzyıla hazırlanmasında dünya vatandaşl1k becerilerinin önemi birçok kurum ve kuruluş tarafindan dile getirilmektedir (Oxfam, 2015; UNESCO, 2014) Dünya vatandaşı bireyin dünya sorunlarına karşı duyarlı, katılımcı, farklı kimliklere saygıll, empatik, eşitlikçi, adil, hak savunucu, hem kendi kültürünü hem de farklı kültürlerin özelliklerini öğrenmede istekli, eleştirel düşünen, yaşamboyu öğrenen özelliklerine sahip olması gerektiği savunulmaktadır (Holvoet, 2010; Kronfli, 2011; Oxfam, 2015). 


\subsection{Eleștirel Düșünme:}

Dil Kurumu eleştiri kavramını edebiyat ve sanat gibi alanları açısından "Bir insanı, bir eseri, bir konuyu doğru ve yanlış yanlarını bulup göstermek amacıyla inceleme işi, tenkit"; felsefi bakımdan "özellikle bilginin temellerini ve doğruluk durumunu inceleme, sınama, yargılama" şeklinde tanımlamıştır (https://sozluk.gov.tr/) tarihsel süreçte eleştiri kavramı uzun süre "rekonstrüksiyon, yeniden kurma" olarak anlamlamlandırılmıştır. Eleştirel düşüne yarım asırdır literatürde yer almış, giderek farkındalıklar artmıştır (Jackson, 1991). "Sokratik sorgulama" yöntemi "gerçekte ED stratejisidir" (Vardyan, Asadyan, tarihsiz; Kökdemir, 2012). "Eleştirinin belki de en önemli özelliği, bilgiyi kişisel kanılara değil, yönteme, tartışmaya ve fikir alışverişine bırakmasıdır" (Kökdemir, 2012).

ED bilimsel düşünme "yöntem ve stratejilerini" kullanma becerisini gerektirir. Ennis (1985) sorun veya tezin temeline inme, nedenlerini inceleme, güvenilir kaynaklar bulma, bütüncül bakma, ana konuyu odak alma, alternatiflere arama, açık ve net olma, kanıtlara göre yönlenme, karmaşıklıkları sınıflama, ilgili herkesten yararlanabilme şeklinde kapsayıcı bir tanım yapmıştır. Aynı yazara (1993) göre ED "neye inanılacağı veya ne yapılacağına karar vermedir". Rudinow ve Barry'e (2008) göre bu akıl yürütmeyle zihinsel stratejiler kullanmayı gerektirir. ED öz değerlendirme ve içsel muhakemeyi içeren "amaçlı, nedenli ve hedefe yönelik" bir uygulamadır. Böylelikle kişiler bütüncül bir perspektifle "yorumlama ve analiz ve değerlendirme" sürecini takip ederler Şenşekerci ve Bilgin (2008: 39).

Yapıcı eleştirinin en önemli farkı kişisellik yerine yönteme odaklanarak tartışma ve fikir alışverişi sonucu ulaşmasıdır. Facione (2004) ED'yi analiz etme, yorumlama, özyönetim, çıkarsama, açıklama ve değerlendirme, Dawsonl (2008) problemi kavrama ve tanımlama, bilgi toplama ve değerleme, ölçüt koyma, seçeneklerden tercih yapma, geliştirme ve bunları açıkça iletebilmektir. ED toplumsal yaşamdaki "eleştiri” kavramına yüklenen olumsuzlukla eşdeğer tutulsa da, aynı şey değildir. ED olumludur, iyiliği ve gelişmeyi hedefler (Quinn, 2000), "sabit bir fikre şartsız koşulsuz" uyumu kabul etmez ve yenilikçi verileri destekler (Şenşekerci ve Bilgin, 2008). ED’nin "analitik, değerlendirici ve yaratıcı" yanı yaratıcı düşünmeyle karıştırılmakta; özellikle medyada farklı düşünme yaratıclıkla özdeşleşleştirilmekte, ED ise eksik bulmak gibi sunulmakta ve "iyi bir şey olmadığına ilişkin izlenimleri pekiştirilmektedir" (Paul, Elder, 2012).

$\mathrm{Bu}$ şekildeki etkilerle veya kültürel olarak ED’ye bazen reaksiyonel yaklaşlabilmektedir (Paul, Elder, 2012: 3-20). Alversons ve Spicer (2012) ise alış1lagelmiş sunum ve dayatmalar sorgulandığı için ED'ye tepkilerin olabildiğinden bahsetmektedirler. Haskins'in (2006) ED'nin "hata arama ya da negatif düşünme" değildir şeklindeki ifadesiyle konunun bu boyuta indirgenmesine eleştirel yaklaşmaktadırlar. Paul ve Elder'in (2012) tarafsız değerlendirme olarak nitelediği ED'ye olumsuz tutumları azaltmanın en iyi yolu konuları ifade ederken kullanılan "dil, tutum ve tarzdır". Ennis (1985) ED süreci diğerleri iletişim halinde sorun çözmeyle başlarlar, eski ve yeni bilgiler muhakeme ederken "tümevarım ve tümdengelim" yolu kullanır, neye inanıp inanılmayacağı hakkında bir karara varma ile sona erer. Sorun çözme probleme ilişkin parçaları birleştirerek eyleme geçme düzeyi, ED ise çözümden önce kapsamı iyice anlamak için mevcut bilginin analizi ve değerlendirilme sürecidir (Özer, 2002; Ulupınar, 1997) ve çözümün kalitesini artırmaya çalışırken düşünme biçimidir Kökdemir, 2012'ye göre ED ile ilgili yetenekler şöyle sıralanabilir: (1) Kanıtlı gerçeklikler ve iddialar arasındaki farkı yakalayabilme, (2) elde edilen verilerin test edilmesi, (3) gereksiz bilgileri ayıklama, (4) önyargı gibi olumsuzlukların farkında olma, (5) tutarsızlıkları fark etme, (6) etkili soru sorabilme, (7) "sözlü ve yazılı dili etkili kullanabilme" ve (8) üst bilişi kullanabilme becerileridir.

Eleştirel düşünen bireyleri yetiştirmek okulların işidir. Eleştirel düşünmeyi bütüncül olarak davranışlarına yansıtan eğitimciler okullarda, fakültelerde, sınıflarda ilişkisellik, neden ve kanıta inanış, açılılık, meraklılık ile hoşgörü, doğruyu arama, şüpheci olma ve üst-düzey soru sorma gibi ED göstergelerini sergileyici bir yapıda olmalıdırlar. Böylelikle sınıfta eğiticiler eleştirel düşünmeyi destekleyici her türlü özelliği taşımalılar ve bu konuda öğrencilerini yetiştirmek için 
çaba harcanmalıdır. Öğretim programlarıyla ED yaşama geçirmek zordur (Alkın, 2012). Özellikle de daha küçük yaşlarda ilk ve ortaokul öğretmenleri eleştirel düşünmeyi içermesi gereken gizilörtük programa daha da yoğunlaşmalıdırlar.

\subsection{Kavramsal Çerçeve}

Okullar öğrencilerini düşünme yetileri gelişmiş, konuları ilişkilendirebilen, "doğru yöntemlerle sorun çözebilen", esnek, yenilikçi, risk alan, girişimci ve yaratıcı yetiştirmelidir (Paulus, 2000; Torrance, 1968). Burada "yaratıcılık yeni yollar aramayı, kesin doğrulara şüpheyle bakmayı ve risk alabilmeyi” gerektirir (Aslan, 1994). ED yaratıc1lı ve problem çözme becerileri eğitimin önemli bir parçası olarak kabul edilir. Bilgiye ulaşmayı bilen bu becerilere sahip öğrenciler, "internet ve destek teknolojik araçlar aracılığıyla küresel dünyayı her yönüyle anlama ve analiz etme becerisi kazanabileceklerdir". Bu yapıdaki öğrenciler diğer kültürleri tanıma ve empati kurma konusunda zorluk yaşamazlar. Tabiki hızlı gelișme ve değișmenin olduğu günümüzde bilgilerin okul yılları ile sınırlı kalması bir hezeyan haline gelebilir. Alanyazında saptandığ1 ve tartışıldığ 1 gibi teknolojinin merkeze alındığı bugünün ve yarının dünyayasında eleştirel yaklaşımlar ve hayat boyu öğrenme becerilerinin geliştirlmesi önem kazanmaya devam etmektedir (Abdelhafez, 2014; Caesar, Jawawi, Matzin, Shahrill, Jaidin, Mundia, 2016; Celuch, Slama, 1998; Deveci ve Ayish, 2017; Nasr, 2008).

YBÖ için bazı becerilerin edinilmesinde ED yaşamsal bir rol oynar. Bireyler eleştirel yaklaşımlarla "gerek içerik" gerekse "herhangi bir disiplinin düşünme sistemi bakımından" yaşamsal becerileri öğrenebilirler. Bunun yanında eleştirel yaklaşımla ilerleyen öğretim sürecindeki ders veya kursların kapsamı tek tip bir içerikle değil, yeni yaklaşımlarla problemlerle başa çıkmayı içerecek şekilde yeniden kavramsallaştırılmalıdırlar. Bu durumda seçici bir şekilde "güne uygun dil ve bağlamları kullanmaya yönelen öğrenciler aynı zamanda ilişkisel sorunlarını da çözme becerisine sahip olurlar. Öğrencilere tek bir cevap aramak yerine, birden çok cevap armaya yöneltecek düşünme tarzının kazandırılması esas alınmalıdır (Celuch, Slama 1998).

Aşağıdaki argümanlar, formal eğitim ortamlarında veya dişında öğrenmeyi içerir ve bir taraftan kalkınma ve küresel vatandaşlık ilişkisini ele alırken diğer taraftan eleştirel düşünmeye atıfta bulunur. Şekil 1'de küresel vatandaşlık ED ve YBÖ ilişkisine 1şık tutan bir yapıda olması itibarıly incelemek yerinde olacaktır.
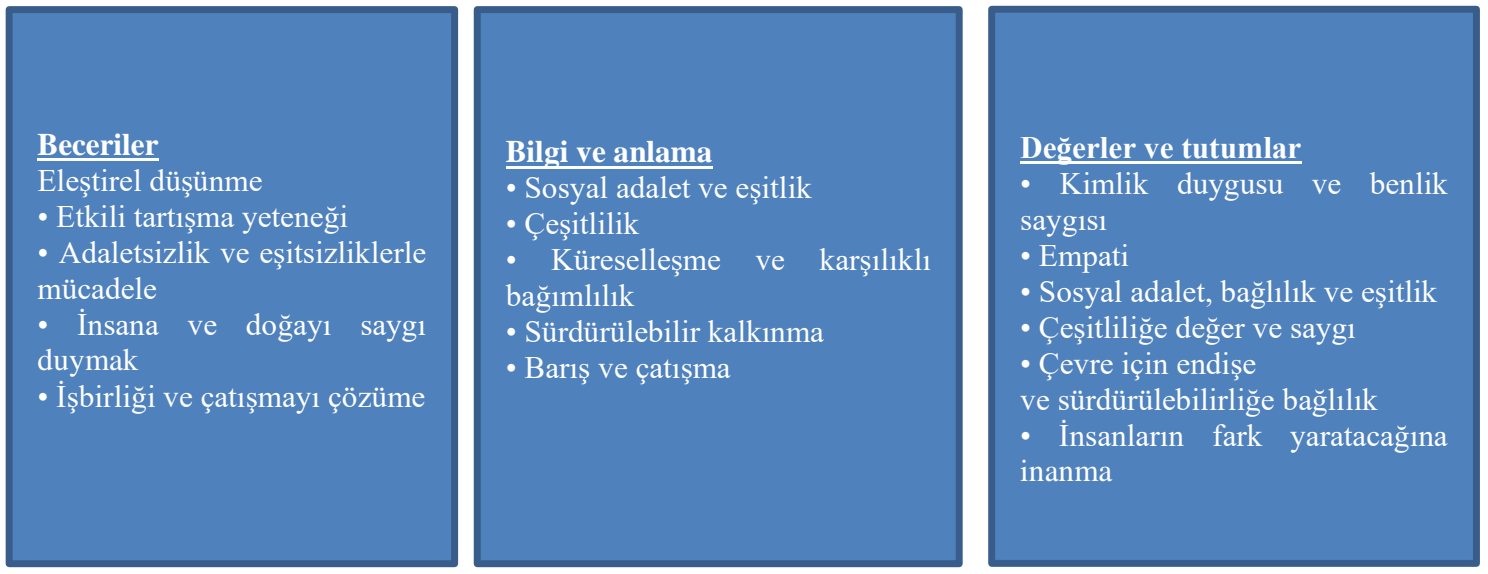

Şekil 1. Sürdürülebilir Kalkınma ve Küresel Vatandaşl1k Eğitimi (Cyfanfayt, 2008).

Bu sınıflamalar dünya vatandaşlı̆̆ı, ED ve tüm bu bilgi, beceri ve değer ve tutumların kazanılabilmesi ise YBÖ ile ilişkilidir ve sürekli öğrenmeyle gerçekleşebilir. ED becerisi tartışma kültürünü olumlu etkiler ve daha analitik, bilgiye, senteze ve her bilgiyi olduğu gibi kabul emeyen şüpheci yaklaşıma ve bununla beraber iletişim ve dili iyi kullanma anlayış ve alışkanlıklarıyla bunun gerçekleşmesi mümkündür. Sosyal adalet, saygı, empati gibi özelliklerde hem eleştrel 
düşünme hem de dünya vatandaşlığı algısı için önem taşımaktadır. Eleştirel öğrenme teorisi açıkça ED ve kavramsal değişimde çok önemli olmayan öğrenmenin duygusal bir bileşenini içerir. Sosyal bir kurum olarak bilgi kavramı eleştirel teoride önemlidir. Bilginin üretimi, sosyal gücün bir ifadesidir ve dünyayı şekillendirmedeki eylemle ayrılmaz bir şekilde bağlantılıdır. İktidarlar kültürel anlamları ve bu anlamları dayatmayı olası tek bir gerçekmiş gibi uygulamayı dikkate alırlar. Eleştirel pedagoji, bu "gerçekler" hakkında eleştirel bir yansıtma teşvik etmeyi, öğrencilere alternatifleri düşünmeleri için meydan okumalarını ve onlara göre hareket etmeyi amaçlamaktadır (Bolhuis, 2003).

Holvoet vd. (2010) araştırmalarında üniversite öğrencilerinin dünya vatandaşlıklarının temel özelliklerini şöyle belirlemişlerdir: Küresel vatandaşlık kavramını tanımlayan "kapsayıcı bir dünya görüşü, dayanışma duygusu ve felsefi bir arka plan" olmak üzere üç ana unsurdan bahsedilmktedir: Katılımcılar, kapsayıcı bir dünya vizyonunu, farklı kıtaların, bölgelerin, grupların ekonomik, politik, kültürel ve etik süreçlere bağımlılıkla ilişkilendirilir. Dayanışmaya ise bir duygu olarak bakılır. Üçüncü unsur felsefi bir arka plan küresel, vatandaşlık yorumunun değersiz olmadığı gerçeğinin göstergesi olarak kabul edilir.

\section{YÖNTEM}

$\mathrm{Bu}$ çalışmada, öğretmen adaylarının, YBÖ, dünya vatandaşlığı yeterlik algıları ve ED arasındaki yapısal ilişkileri incelemek amacıyla çok faktörlü yordayıcı korelasyonel desen kullanılmıştır. Çalışmada bir yordayıcı değişken olması durumunda tek faktörlü yordayıcı korelasyonel desene; iki veya daha çok yordayan değişken olması durumunda ise çok faktörlü yordayıcı korelasyonel desene başvurulmaktadır (Büyüköztürk, Çakmak, Akgün, Karadeniz, Demirel, 2017). Bu araştırmada yaşam boyu öğrenme eğilimi ve dünya vatandaşlığı yeterlik algısı yordayıcı değişken olarak, eleştirel düşünme eğilimi ise yordanan değişken olarak belirlenmiştir. $\mathrm{Bu}$ değişkenler arasındaki ilişkileri tanımlayan hipotetik model yapısal eşitlik modellemesi aracılığılla test edilmiştir.

\section{1. Çalıșma Grubu}

Araştırmaya iki devlet üniversitesinde açılan pedogojik formasyon derslerine devam eden, Türk Dili ve Edebiyatı, Biyoloji, Fizik, Matematik, Tarih, Muhasebe, Felsefe, Sosyoloji, Sağlık bölümlerinden 508 öğretmen adayı katılmıştır. Öğretmen adaylarının \%65,4'ü (n=332) kadın ve $\% 34,6$ 'si (n=176) erkektir.

\subsection{Veri Toplama Araçları}

Veri toplamada "Kaliforniya Eleştirel Düşünme Eğilimi Ölçeği”, "Dünya Vatandaşlığı Yeterlik Algı Ölçeği” ve "Yaşam Boyu Öğrenme Eğilimleri Ölçeği” kullanılmıştır.

\subsubsection{Kaliforniya Eleştirel Düşünme Eğilimi Ölçeği}

Ölçek, Facione, Facione ve Giancarlo ve diğerleri (1998) tarafindan üniversite öğrencilerinin eleştirel düşünme eğilimlerini ortaya koymak amacıyla geliştirilmiştir. Ölçeğin Türkçe'ye uyarlama çalışmaları Kökdemir (2003) tarafından yapılmıştır. Orijinal ölçek toplam 75 maddeden ve doğruyu arama $(\mathrm{r}=.44)$, açık fikirlilik $(\mathrm{r}=.44)$, sistematiklik $(\mathrm{r}=.44)$, kendine güven $(\mathrm{r}=.44)$, analitiklik $(\mathrm{r}=.44)$, merakl1l1k $(\mathrm{r}=.44)$, olgunluk $(\mathrm{r}=.44)$ olmak üzere yedi alt boyuttan meydana gelmektedir. Alt ölçeklere ait iç tutarlık katsayısı (Cronbach Alpha).72 ile .80 arasında değişirken toplam ölçeğin iç tutarlık katsayısı .90 olarak tespit edilmiştir. Likert yapıda olan ölçeğin her bir maddesi 1 (hiç katılmıyorum) ile 6 (tamamen katılıyorum) arasında derecelendirilmektedir. Uyarlama çalışmaları sonucunda altı alt ölçekli ve 22'si olumsuz 51 maddeli bir yapıya ulaşı1mıştır. Analitiklik $(\mathrm{r}=.75)$ alt ölçeğinde 10 madde; açık fikirlilik $(\mathrm{r}=.75)$ alt ölçeğinde 12 madde; meraklılık ( $\mathrm{r}=.78)$ alt ölçeğinde 9 madde; kendine güven $(\mathrm{r}=.77)$ alt ölçeğinde 7 madde; doğruyu arama $(\mathrm{r}=.61)$ alt ölçeğinde 7 madde ve sistematiklik( $\mathrm{r}=.63)$ alt ölçeğinde 6 madde yer almaktadır. Bu alt ölçeklerin iç tutarlık katsayıları (Cronbach Alpha) 61 
ile .78 arasında değişmektedir. Ayrıca doğrulayıcı faktör analizi sonucunda uyum indeksleri $\mathrm{RMR}=.049, \mathrm{GFI}=.86, \mathrm{AGFI}=.84$ olarak tespit edilmiştir (Kökdemir, 2003). Bu çalışmada ölçeği analitiklik iç tutarlık katsayısı $(\mathrm{r}=.76)$, açık fikirlilik iç tutarlık katsayısı $(\mathrm{r}=.59)$, meraklılık iç tutarlık katsayısı $(\mathrm{r}=.80)$, kendine güven iç tutarlık katsayısı $(\mathrm{r} .80)$ doğruyu arama iç tutarlık katsayısı $(\mathrm{r}=.59)$, sistematiklik iç tutarlık katsayısı $(\mathrm{r}=.65)$, ölçeğin tamamına ait iç tutarlık katsayısı $(\mathrm{r}=.85)$, olarak hesaplanmıştır. Alanyazın incelendiğinde farklı dillere uyarlanması sürecinde gerek güvenirlik kat sayıları ile ilgili gerekse alt boyutlara maddelerin dağılmasıyla ilgili sorunlar yaşandığı anlaşılmaktadır (Kökdemir,2003; Osman, Halim ve Iksan, 2003; Yeh, 1996). Eleştirel düşünme eğilimlerini ortaya koyan farklı bir Türkçe ölçek bulunmaması nedeniyle Kökdemir tarafından Türkçeye uyarlanmış Kaliforniya Eleştirel Düşünme Eğilimi Ölçeği kullanılmıştır. Bu çalışmada iç tutarlık katsayısı .65 ve üzerinde olan analitiklik, meraklılık, kendine güven, sistematiklik alt ölçekleri kullanılmıştır.

\subsubsection{Dünya Vatandaşı̆̆ı Yeterlik Algı Ölçeği}

Şahin, Şahin ve Göğebakan Yıldız (2016) tarafından geliştirilen bu ölçek üniversite öğrencilerinin dünya vatandaşlığı yeterlik algısını tespit etmeyi amaçlamaktadır. Beş maddelik tek faktörlü bir yapıda olan bu ölçeğin iç tutarlık katsayısı (Cronbach Alpha) .80'dir. Likert tipi olan ölçeğin her bir maddesi 1 (hiç katılmıyorum) ile 5 (tamamen katılıyorum) arasında değerlendirilmektedir. Dünya Vatandaşlığı Yeterlik Algı Ölçeği için tespit edilen bu yapının doğrulanması amacıyla doğrulayıcı faktör analizi yapılmıştır. Model veri uyumu istatistikleri incelendiğinde $\mathrm{RMSEA}=.072, \quad \mathrm{~S}-\mathrm{RMR}=.048, \quad \mathrm{CFI}=.97, \quad \mathrm{AGFI}=.94, \quad \mathrm{GFI}=.98$ olarak hesaplanmıştır. Bu çalışmada ölçeğin iç tutarlık katsayısı $(r=.75)$ olarak hesaplanmıştır.

\subsubsection{Yaşam Boyu Öğrenme Eğilimleri Ölçeği}

Ölçek Coşkun Diker (2009) tarafından üniversite öğrencilerinin yaşam boyu öğrenme eğilimlerini belirlemek amacıyla geliştirilmiştir. Ölçek geliştirme sürecinde ilk olarak 74 maddelik bir ön deneme formu oluşturulmuştur. Yapılan deneme uygulaması sonucunda ulaşılan veriler üzerinden faktör analizi gerçekleştirilmiştir. Bu analiz sonucunda yaşamboyu öğrenmeyi olumlu ve olumsuz etkileyeceği düşünülen dört faktörlü yapıya ulaşılmıştır. Bu alt ölçekler sırasıyla motivasyon (6 madde), sebat (6 madde), merak yoksunluğu (9 madde) ve öğrenmeyi düzenlemede yoksunluk (6 madde) olarak tespit edilmiştir. Ölçekte toplam 27 madde yer almaktadır. Maddeler 1 (hiç uymuyor) ile 6 (çok uyuyor) arasında değerlendirilmektedir. Ölçeğin iç tutarlık katsayısı (Cronbach Alpha) .89 olarak hesaplanmıştır. Bu çalışmada motivasyon iç tutarlık katsayısı $(\mathrm{r}=.84)$, sebat iç tutarlık katsayısı $(\mathrm{r}=.84)$, ve merak yoksunluğu iç tutarlık katsayısı $(\mathrm{r}=.68)$, öğrenmeyi düzenlemede yoksunluk iç tutarlık katsayısı $(\mathrm{r}=.83)$, ölçeğin tamamına ait iç tutarlık katsayısı $(r=.90)$, olarak tespit edilmiştir.

\subsection{Veri Toplama Süreci}

"Kaliforniya Eleştirel Düşünme Eğilimi Ölçeği”, "Dünya Vatandaşlığı Yeterlik Alg1 Ölçeği”, ve "Yaşam Boyu Öğrenme Eğilimleri Ölçeğì" gönüllülüğe dayalı olarak öğretmen adayları tarafından yanıtlanmıştır. Yanıtlanan ölçekler incelenmiş, eksik ya da hatalı doldurulan 27 ölçek formu işleme katılmamıştır. Sonuç olarak 535 ölçek formundan 508'i geçerli sayılmış ve analiz işlemleri bu veriler üzerinden yapılmıştır.

\subsection{Verilerin Çözümlenmesi}

Dünya vatandaşlığı yeterlik algısı, eleştirel düşünme ve yaşam boyu öğrenme eğilimi arasındaki ilişkilere yönelik oluşturulan modelin test edilmesinde Yapısal Eşitlik Modellemesi kullanılmıştır. Yapısal eşitlik modellemesi, gözlenen ve gizil (gözlenmeyen) değişkenler arasındaki nedensel ve ilişkisel yapılara ilişkin hipotezlerin test edilmesinde kullanılan kapsamlı bir istatistik yöntemidir (Hoyle, 1995) Alanyazında sıklıkla ölçüm modeli ve yapısal modelden oluşan iki aşamalı Yapısal Eşitlik Modellemesi önerilmektedir (Joreskog ve Sörbom, 1996). Bu doğrultuda gözlenen değişkenlerin gizil değişkenleri yeterli düzeyde temsil edip etmediğini belirlemek amacıyla ölçüm modeli oluşturulmuştur. Ardından yapısal modelin analizine 
geçilmiştir. Yapısal Eşitlik Modellemesi Ek olarak değişkenlere ait betimsel istatistikler ve korelasyonlar hesaplanmıştır. Analizlerde AMOS ve SPSS programı kullanılmıştır.

\section{BULGULAR}

Çalışmada ölçüm modelinde tanımlı 3 gizil, 13 gözlenen değişken vardır. Bu kısımda eleştirel düşünme gizil değişkeni analitiklik, kendine güven, meraklılık, sistematiklik gözlenen değişkenlerinden, yaşam boyu öğrenme gizil değişkeni motivasyon, sebat öğrenmeyi düzenlemede yoksunluk, merak yoksunluğu gözlenen değişkenlerinden ve dünya vatandaşlığ gizil değişkeni beş maddelik gözlenen değişkenlerinden oluşmaktadır. 3 örtük ve 13 gözlenen değişkenin yer aldığı ölçüm oluşturulmuş ve bu ölçüm modelinin veri ile uyumluluğu test edilmiştir. Analizler sonucunda ölçüm modeline ilişkin path diyagramı Şekil 2'de gösterilmiştir.

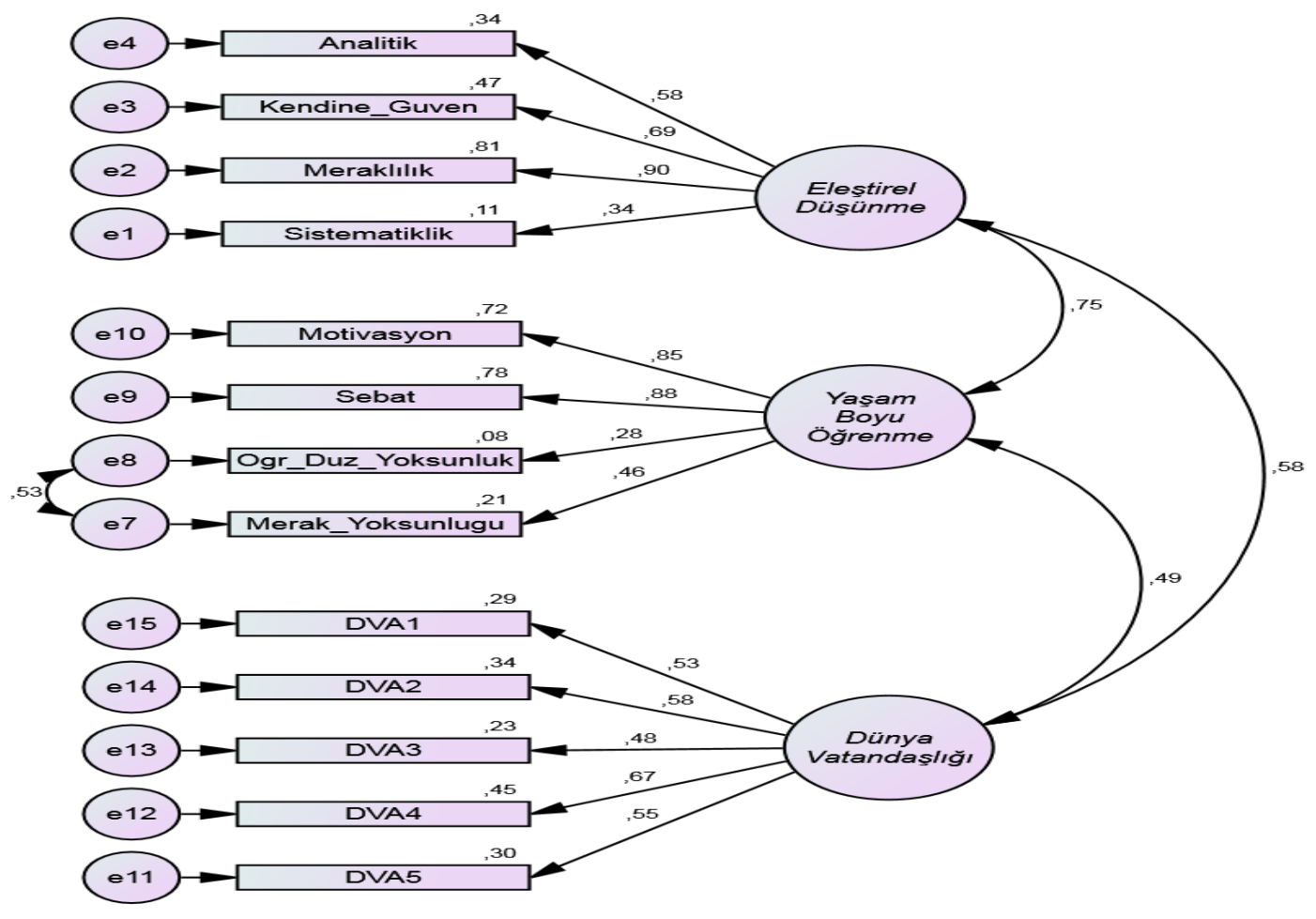

Şekil 2. Ölçüm Modeli

Ölçüm modeline ait uyum istatistikleri incelendiğinde Ki-kare $\chi 2=233,203, \mathrm{sd}=61 \mathrm{p}=0,00$ düzeyinde anlamlı olduğu tespit edilmiştir. Ki-kare ile serbestlik derecesi arasındaki oran ise $(\chi 2 /$ sd $=3,823)$ olarak hesaplanmıştır. Ölçüm modelinde öğrenmeyi düzenlemede yoksunluk ve merak yoksunluğuna ait hata terimleri arasında kovaryans kurularak bir modifikasyon yapılmış uyum iyiliği değerleri yeterli düzeyde olduğu ve ölçüm modelinin doğrulandığ1 görülmüştür. Uyum iyiliği indeksleri hesaplandığında AGFI=,906, GFI=,937, CFI=,919, ve RMSEA=,075 sonuçlarına ulaşılmıştır. Şekil 1'de görüldügü gibi oluşan son ölçüm modeliyle gözlenen değişkenler yapısal model oluşturmaya hazır hale gelmiştir. Sonraki aşamada tüm değişkenler arasındaki korelasyonlar, ortalama ve standart sapma değerleri hesaplanmıştır. Ulaşılan sonuçlar Tablo 1'de sunulmuştur. 
Tablo 1. Ortalama, Standart Sapma ve Değişkenler Arası Korelasyon Değerleri

\begin{tabular}{|c|c|c|c|c|c|c|c|c|c|c|c|c|c|c|c|}
\hline Değişkenler & $\mathbf{M}$ & SD & 1 & 2 & 3 & 4 & 5 & 6 & 7 & 8 & 9 & 10 & 11 & 12 & 13 \\
\hline \multicolumn{16}{|l|}{ Eleştirel Düşünme } \\
\hline 1. Analitiklik & 4,9 &, 54 & & & & & & & & & & & & & \\
\hline 2.Kendine Güven & 4,2 &, 81 &, $45^{* *}$ & & & & & & & & & & & & \\
\hline 3. Meraklılık & 4,6 &, 73 &, $53^{* *}$ &, $61^{* *}$ & & & & & & & & & & & \\
\hline 4.Sistematiklik & 4,4 &, 72 &, $34^{* *}$ &, $30^{* *}$ &, $26^{* *}$ & & & & & & & & & & \\
\hline \multicolumn{16}{|l|}{ Yaşam Boyu Öğrenme } \\
\hline 5. Motivasyon & 5,2 & ,64 &, $37^{* *}$ &, $41^{* *}$ &, $60^{* *}$ &, $20^{* *}$ & & & & & & & & & \\
\hline 6.Sebat & 4,5 & 86 &, $31^{* *}$ &, $45^{*}$ &, $61^{* *}$ &, $24^{* *}$ &, $75^{* *}$ & & & & & & & & \\
\hline $\begin{array}{l}\text { 7.Öğrenmeyi Düzenlemede } \\
\text { Yoksunluk }\end{array}$ & 5,1 &, 85 &, $25^{* *}$ &, $11^{*}$ &, $20^{* *}$ &, $37^{* *}$ &, $27^{* *}$ &, $22^{* *}$ & & & & & & & \\
\hline 8. Merak Yoksunluğu & 4,6 &, 91 &, $14^{* *}$ &, $19^{* *}$ &, $31^{* *}$ &, $36^{* *}$ &, $37^{* *}$ &, $43^{* *}$ &, $58^{* *}$ & & & & & & \\
\hline \multicolumn{16}{|l|}{ Dünya Vatandaşlığı } \\
\hline 9.DVA1 & 3,2 & 1,1 &, $09^{*}$ &, $21^{* *}$ &, $27^{* *}$ &, 04 &, $19^{* *}$ &, $21^{* *}$ &, 07 &, $12^{* *}$ & & & & & \\
\hline 10.DVA2 & 3,9 & 89 &, $17^{* *}$ &, $23^{* *}$ &, $33^{* *}$ &, 07 &, $22^{* *}$ &, $23^{* *}$ &, $13^{* *}$ &, $17^{*}$ &, $36^{* *}$ & & & & \\
\hline 11.DVA3 & 3,4 & 1,2 &, 07 &, $21^{* *}$ &, $22^{* * *}$ & ,03 &, $16^{* *}$ &, $20^{* *}$ & ,07 &, $12^{* *}$ &, $27^{* *}$ &, $31^{* *}$ & & & \\
\hline 12.DVA4 & 3,3 & 1,0 &, $09^{*}$ &, $30^{* *}$ &, $36^{* *}$ &, $14^{* *}$ &, $35^{* *}$ &, $35^{* *}$ & 07 &, $11^{*}$ &, $37^{* * *}$ &, $38^{* *}$ &, $33^{* *}$ & & \\
\hline 13.DVA5 & 3,9 &, 92 &, $13^{* *}$ &, $24^{* *}$ &, $33^{* *}$ &, $13^{* *}$ &, $24^{* *}$ &, $20^{* *}$ &, 05 &, 08 &, $24^{* *}$ &, $33^{* *}$ &, $25^{* *}$ &, $39^{* *}$ & 1 \\
\hline
\end{tabular}

$* \mathrm{p}<0,05, * * \mathrm{p}<0,01$

Sonraki aşamada, eleştirel düşünme eğilimi ile yaşam boyu öğrenme eğilimleri ve dünya vatandaşlığı yeterlik algıları arasındaki doğrudan ilişki test edilmiştir. Yapısal model Şekil 3'de gösterilmiştir.

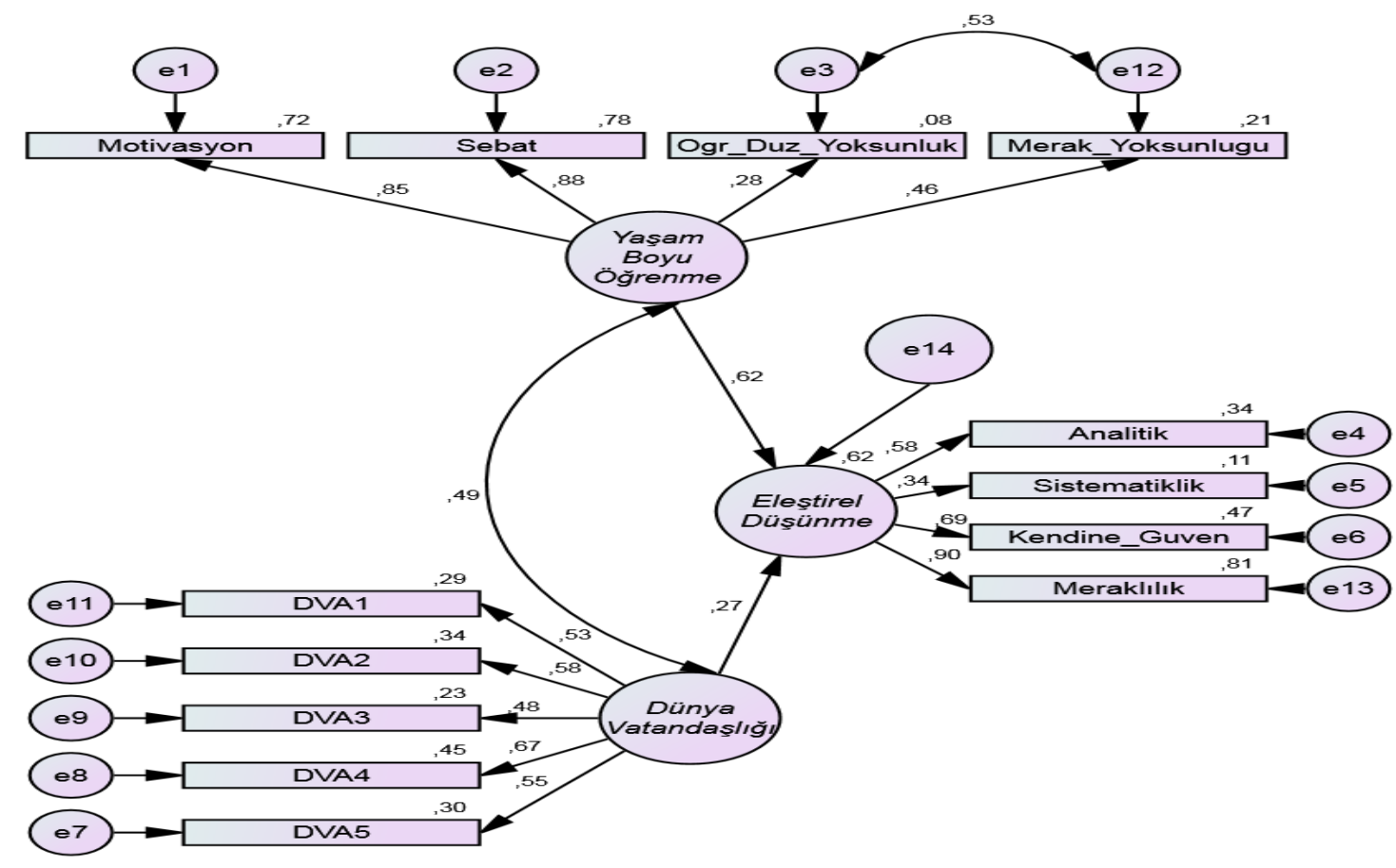

Şekil 3. Eleştirel Düşünme Eğilimi, Yaşam Boyu Öğrenme Eğilimi ve Dünya Vatandaşlığ Yeterlik Algısı Arasındaki Yapısal Model 
Yapısal modele ait uyum istatistikleri incelendiğinde Ki-kare $\chi 2=233,203, \mathrm{sd}=61 \mathrm{p}=0,00$ düzeyinde anlamlı olduğu tespit edilmiştir. Ki-kare ile serbestlik derecesi arasındaki oran ise $(\chi 2 / s d=3,823)$ olarak hesaplanmıştır. Uyum iyiliği indeksleri hesaplandığında AGFI=,906, $\mathrm{GFI}=, 937, \mathrm{CFI}=, 919$ ve RMSEA=,075 sonuçlarına ulaşılmıştır. Bu değerler model veri uyumunun kabul edilebilir düzeyde iyi olduğunu göstermektedir (Jöreskog ve Sörbom, 1993; Marsh ve Hocevar, 1988). Test sonuçları dünya vatandaşlığı ve YBÖ bağımsız ED bağımlı değişkeni olarak oluşturulan modelde elde edilen uyum indeksleri, modelin kabul edilebilir sınırlar içerisinde olduğunu göstermektedir. Sonuç olarak YBÖ ve dünya vatandaşlığının her ikisi de ED'yi yordamaktadır.

\section{TARTIŞMA, SONUÇ VE ÖNERILER}

Araştırmanın sonuçları eleştirel düşünme, yaşam boyu öğrenme ve dünya vatandaşlığı arasında orta ve düşük düzeyde anlamlı ilişkiler olduğunu göstermiştir. Bunlardan ilk olarak eleştirel düşünme ile yaşam boyu öğrenme arasındaki ilişkide; diğerleri düşük düzeydeyken analitik düşünme kendine güven ve merakl1lık ile YBÖ'nün motivasyon ve sebat boyutları arasında; sistematik olmayla öğrenmeyi düzen koyma ve meraklılık arasında orta düzeyde ilişki saptanmıştır. Trilling, Fadel'e (2009) göre de eleştirel düşünme becerisi, yaşam boyu öğrenmenin en önemli tanımlayıcılarından biridir. Green (2015) bu iki beceri arasındaki güçlü bağa dikkat çekerken, yüksek öğrenim öğrencilerinin eleştirel düşünme becerilerinin gelişmesinin yolunun yaşam boyu öğrenen birey olmaktan geçtiğini belirtir. Nitekim alanyazın incelendiğinde bu iki beceri arasında pozitif yönlü ilişkiler olduğunu gösteren araştırmalara rastlanmaktadır (Celuch, Slama, 1998; Deveci ve Ayish, 2017).

Öğretmen adaylarından elde edilen bulgulara göre, ED ve dünya vatandaşlığı arasında da pozitif yönlü düşük düzeyde bir ilişki saptanmıştır. Bu sonuç eleştirel düşünmenin dünya vatandaşı olma ilkelerini benimseyip uygulayan bireylerin en önemli yetilerinden biri (Oxfam, 2015) olması varsayımıyla paralel düşmektedir. Dünya vatandaşı olanlar eleştirel düşünen, iletişim akımları yüksek, insanlığa ilişkin empati yapabilen (Dutoğlu ve Tuncel, 2008; Kan, 2009), evrensel yaşamın bugünü ve yarınının problemlerinin çözümüne katkı sağlayan bireydir. Diğer yandan bu yapıdaki bireyler soru soran, sorgulayan, bilinçliliği yüksek ve aktif davranırlar (Kan, 2009). Tüm bu özelliklere sahip vatandaşların gereksinim duydukları yetilerden biri ise ED becerisidir (Ten Dam, Volman, 2004). ED inanılması ve yapılması gerekenleri bilişsel stratejilerle muhakeme ederek karar alma işlemlerini ifade der (Ennis, 1993; Rudinow, Barry, 2008). Alanyazın incelendiğinde eleştirel düşünme ve dünya vatandaşlığı arasındaki bu ilişkiyi Kaya ve Sarıçam (2016) tarafından ortaya koyulmuştur.

Araştırmanın sonuçlarından biri de dünya vatandaşlığı ile YBÖ arasındaki ilişki YBÖ’nün motivasyon ve sebat boyutları ile DVA4 orta düzeydeyken diğer boyutlar açısından düşük düzeyde seyretmiştir. YBÖ bireysel toplumsal ve küresel problemlerin çözümüne fiili katılım için bireyleri geliştirmenin önemli bir yoludur (European Commission, 2001). Bu tanım ile YBÖ ve dünya vatandaşı bireyin arasındaki ilişkiye dikkat çekilmekte, yaşam boyu öğrenme eğiliminin dünya vatandaşı bireylerin en önemli özelliklerinden biri olduğu anlaşılmaktadır. Holvoet vd. (2010) yükseköğrenimin dünya vatandaşı bireyleri yetiştirmesinde YBÖ’nin yerini incelemişler; YBÖ'nin öğretim programlarını esnekleştirerek “uluslararasılaşmayı" artırdığını ve dünya vatandaşlığı için çatı vazifesi gördüğünü saptamışlardır. Nitekim UNESCO (2014) dünya vatandaşlığı eğitimi YBÖ perspektifine dayandırmıştır. Cyfanfayt (2008) YBÖ’nin sürdürülebilir kılınması aracılığıyla çevre sorunlarına duyarlılık başta olmak üzere okulların eğitim içeriklerinde dünya vatandaşlığı eğitimine ağırlık vermesi gerektiğini ortaya koyan bir araştırma raporuyken Jenkins'ın (2018) araştırmasında da YBÖ’nün dünya vatandaşlığı için hayati rolü ortaya konulmuştur. 
Araştırmanın nihai sonucuna göre öğretmen adaylarının görüşleri doğrultusunda YBÖ ve dünya vatandaşlığının ED’ye etkisi ortaya konulmuştur. Buna göre YBÖ ile dünya vatandaşlığ 1 arasındaki ilişki orta düzeydeyken, YBÖ ED'yi orta düzeyde yarıdan fazla oranla ve dünya vatandaşlığı ED'yi düşük düzeyde dörtte bir orandan fazla açıklamaktadır. Rakamsal olarak açıklama oranları dikkat çekicidir. Üniversitelerde öğretin elemanları ve öğrenci hareketliği hem dünya vatandaşlığını (Holvoet vd., 2010) geliştirmeye yardım ederken hem de YBÖ için bir doğal fırsat olmaktadır. Bu araştırmanın sonuçları bu iki öğenin eleştirel sorgulayıcı bakışı artırdığ 1 ve ED'nin gelişmesine katkı sağladığından bir katma değerde yarattıkları ortaya konulmuştur. Buna göre Cyfanfayt'nn (2008) da belirttiği gibi başta eğitim olmak üzere fakülteler ve diğer eğitim kurumları örtük ve YBÖ programlarında "sürdürülebilir kalkınma ve dünya vatandaşlığı ve "küresel perspektifi" içeriklerine dahil ederek başka kurumlara örnek teşkil etmelidirler. Kısaca araştırmacılar tarafından bu üç değişkeni dikkate alarak başka çalışmalar yapabilirler. Eleştirel düşünmeyi etkileyen başka değişkenler araştırılabilir. Bu çalışmalar farklı eğitim kurumlarında gerçekleştirilebilir.

\section{KAYNAKÇA}

Abdelhafez, A. (2014). Experienced EFL teachers' professional practical knowledge, reasoning and classroom decision making in Egypt: Views from the inside out. Teacher Development, $18(2), 229-245$.

Akbıyık, C. ve Seferoğlu, S. S. (2006). Eleştirel düşünme eğilimleri ve akademik başarı. Çukurova Üniversitesi Ë̆itim Fakültesi Dergisi, 3(32), 90-92.

Alkın, S. 2012. Illköğretim öğretmenlerinin eleştirel düşünmeyi destekleme davranışlarının değerlendirilmesi. (Yayınlanmamış Doktora Tezi). Ankara Üniversitesi Eğitim Bilimleri Enstitüsü. Ankara.

Alversons, M. \& Spicer, A. (2012). Critical leadership studies: The case for critical performativity. Human Relation, 65(3), 367-390.

Anı1, K. ve Eranıl, M. Ö. (2017). Öğretmen adaylarının eleştirel düşünme eğilim düzeyleri ile eleştirel liderlik düzeyleri arasındaki ilişkinin incelenmesi. Bildiri Özetleri Kitabı, Conference Proceedings, Pamukkale Üniversitesi, Denizli: Anı Yayıncılık.

Aslan, E., A. 1994. Yaratıcı düşünceli bireylerin psikolojik ihtiyaçları. (Yayınlanmamış Doktora Tezi), Marmara Üniversitesi Sosyal Bilimler Enstitüsü. İstanbul.

Bates, R. (2008). Teacher education in a global context: towards a defensible theory of eacher education. Journal of Education for Teaching, 34(4) 277-293.

Bayat, K. (2014). Öğretmen adaylarının eleştirel düşünme düzeyleri ile akdemik yazma başarıları arasındaki ilişki. Eğitim ve Bilim, 39(173), 155-168.

Beymen Türnüklü, E. ve Yeşildere, S. (2005). Türkiye'den bir profil: 11-13 yaş gurubu matematik öğretmen adaylarının eleştirel düşünme eğilim ve becerileri. Ankara Üniversitesi Eğitim Bilimleri Fakültesi Dergisi, 38(2), 167-185.

Bolhuis, S. (2003).Towards process-oriented teaching for selfdirected lifelong learning: A multidimensional perspective. Learning and Instruction, 13, 327-347.

Büyüköztürk, Ş., Çakmak, E. K., Akgün, Ö. E., Karadeniz, Ş. ve Demirel, F. (2017). Bilimsel araştırma yöntemleri. Pegem Atıf İndeksi, 1-360.

Caesar, M. I. M., Jawawi, R., Matzin, R., Shahrill, M., Jaidin, \& J. H., Mundia, L. (2016). The benefits of adopting a problem-based learning approach on students'learning developments in secondary geography lessons. International Education Studies, 9(2), 51-65. 
Celuch, K. \& Slama, M. (1998). Critical thinking as an integrative theme for teaching lifelong learning skills in marketing. Marketing Education Review, 8(3), 1-12.

Çetinkaya, Z. (2011). Türkçe öğretmen adaylarının eleştirel düşünmeye ilişkin görüşlerinin belirlenmesi. Ahi Evran Üniversitesi Ë̆itim Fakültesi Dergisi, 12(3), 93-108.

Çokluk Bökeoğlu, Ö. ve Yılmaz, K. (2005). Üniversite öğrencilerinin eleştirel düşünmeye yönelik tutumları ile araştırma kaygıları arasındaki ilişki. Kuram ve Uygulamada Eğitim Yönetimi, 41, 47-67.

Coşkun Diker, Y. (2009). Üniversite öğrencilerinin yaşam boyu ögrenme eğilimlerinin bazı değişkenler açısından incelenmesi. (Yayınlanmamış Doktora Tezi), Hacettepe Üniversitesi Sosyal Bilimler Enstitüsü. Ankara.

Coşkun, Y. M. ve Demirel, M. (2012). Üniversite öğrencilerinin yaşam boyu öğrenme eğilimleri. Hacettepe Üniversitesi Eğitim Fakültesi Dergisi, 42, 108-120.

Cyfanfayt (2008). Education for sustainable development \& global citizenship in lifelong: Good practice in Wales. Learning, Report, Wales.

Dawsonl, T. L. (2008). Metacognition and learning in adulthood. Prepared in response to tasking from ODNI/CHCO/IC Leadership Development Office, Developmental Testing Service https://www.devtestservice.org/PDF/ Metacognition.pdf (Erişim: 12 Şubat 2012).

Demirel, M. ve Yağcı, E. (2012). Sınıf öğretmeni adaylarının yaşam boyu öğrenmeye ilişkin algıları. Hacettepe Üniversitesi Eğitim Fakütesi Dergisi, Özel Sayl: 1, 100-111.

Deveci, T. \& Ayish, N. (2017). Correlation between critical thinking and lifelong learning skills of freshman students. Bartin University Journal of Faculty of Education, 6(1), 282-303,

Dutoğlu, G. ve Tuncel, M. (2008). Aday öğretmenlerin eleştirel düşünme eğilimleri ile duygusal zeka düzeyleri arasındaki ilişki. Abant İzzet Baysal Üniversitesi Eğitim Fakültesi Dergisi, $8(1), 11-32$.

Ebbeck, M. (2006). The challenges of global citizenship: Some issues for policy and practice in early childhood. Childhood Education, 82(6), 353-357.

Ekinci, Ö. (2009). Öğretmen adaylarının empatik ve eleştirel düşünme eğilimlerinin incelenmesi. (Yayınlanmamış Yüksek Lisans Tezi). Çukurova Üniversitesi Sosyal Bilimler Enstitüsü. Adana.

Ennis, R. H. (1985). A logical basis for measuring critical thinking skills. Educational Leadership, 43(2), 44-48.

European Commission. (2001). Communication from the commission: making a European area of lifelong learning a reality. Brussels: European Commission.

Evin Gencel, İ. (2013). Öğretmen adaylarının YBÖ yeterliklerine yönelik algıları, Eğitim ve Bilim, 38(170), 137-152.

Facione, P. A, Facione, N. C., \& Giancarlo, C. A. (1998). The California critical thinking disposition inventory. California Academic Press.

Facione, P. A. (2004). Critical thinking: What it is and why it counts. California: Academic Press.

Field, J. \& Leicester, M. (2003). Lifelong learning or permanent schooling? In: J. Field, M. Leicester (Eds.) Lifelong learning: Education across the lifespan. London: Routledge Falmer.

Göğebakan Y1ldı, D. (2018). Global citizenship training program for teacher candidates. Educational Research and Reviews, 13(12), 436-446. 
Goryunova, E. \& Jenkins, D. M. (2017). Global leadership education: Upping the game. Journal of Leadership Education, 16(4), 76-93.

Green, P. (2015). Teaching critical thinking for lifelong learning. In M. Davies, R. Barnett (Eds.) The palgrave handbook of critical thinking in higher education. 107-121. New York: Palgrave Macmillan.

Haskins, G. R. (2006). A practical guide to critical thinking. http://www.fkm.utm.my/ kasim/mech/smj3513/criticalthinking2.pdf (Erişim: 18.6.2020).

Holvoet, E., Lombaerts, K., Engels, N., De Backer, F., \& Vanwing, T., (2010). Lifelong learning as a strategy for educating global citizens within higher education. International Journal of Social Sciences and Humanity Studies, 2(1)55-61.

Hoyle, R. H. (1995). Structural equation modeling: Concepts, issues, and applications. Sage.

İzci, E. ve Koç, S. (2012). Öğretmen adaylarının yaşam boyu öğrenmeye ilişkin görüşlerinin değerlendirilmesi, Adıyaman Üniversitesi Sosyal Bilimler Enstitüsü Dergisi, 5(9), 101-114.

Jackson, M. C. (1991). The origins and nature of critical systems thinking. Systems Practice, 4(2), 131-149.

Jenkins, A. (2004). Women, lifelong learning and employment. Centre for the Economics of Education, London: School of Economics and Political Science.

Jenkins, A. (2018). Education for sustainable development and global citizenship in adult and community learning in Walles: From policy to pedagogy. (Unpublished Phd. Dissertation). Swansea University. Walles.

Jöreskog, K. G. \& Sörbom, D. (1993). LISREL 8: Structural equation modeling with the simplis command language. Lincolnwood: Scientific Software International.

Kan, Ç. (2009b). Değişen değerler ve küresel vatandaşlık kavramı. Kastamonu Eğitim Dergisi, 17(3), 895-904.

Karışan, D. \& Yılmaz Tüzün, Ö. (2017). Adaptation of character and values as global citizens assesment questionnaire into Turkish: Validity and reliability study. Pamukkale University Journal of Education, 42, 74-85.

Kaya M. M. \& Sarıçam H. (2016). The study of relationship between global citizenship and multicultural personality and critical thinking in preservice teachers. https://www.researchgate.net/publication/301779258 (Erişim: 20.3.2020).

Kaya, B. ve Kaya, A. (2012) Teknoloji çağında öğretmen adaylarının küresel vatandaşlık algıları. Sakarya University Journal of Education, 2(3), 81-95.

Knapper, C. \& Cropley, A. J. (2007). Lifelong learning in higher education. (Ed. M.K. McCuddy, H.V.D. Bosch, W.B. MartzJr, A.V. Matveev), Challenges of Educating People to Lead in a Challenging World. London: Croom Helm.

Kökdemir, D. (2003). Belirsizlik durumlarında karar verme ve problem çözme. (Yayınlanmamış Doktora Tezi) Ankara Üniversitesi Sosyal Bilimler Enstitüsü, Ankara.

Kökdemir, D. (2012). Üniversite eğitimi ve eleştirel düşünme. Pivolka, 21, 16-19.

Kronfli, M. (2011). Educating for global citizenship and anexploration of two curricular methods. (Unpublished MA Thesis). University of Toronto Ontario Institute for Studies in Education. Toronto.

Lipman, M. (1988). Critical thinking: What can it be? Educational Leadership, 46(1), 38-43. 
Marsh, H. W. \& Hocevar, D. (1988). A new, more powerful approach to multitrait-multimethod analyses: Application of second-order confirmatory factor analysis. Journal of Applied Psychology, 73(1), 107-117.

Mclean, L. R., Cook, S. A., \& Crowe, T. (2008). Imagining global citizens: Teaching peace and global education in a teacher-education programme. Citizenship Teaching and Learning, 4(1), 50-64.

Nasr, A. (2008). Pre-university educational system in Egypt. In: S. Abdelnabi, M. Hanafi A., A. Rashad, Nasr, A. (Eds), Educational System in Egypt and Global Trends. Cairo: Dar ElKotob Elmasreya.

Ocak, G., Eymir, E. ve Ocak, İ. (2016 ). Öğretmen adaylarının eleştirel düşünme eğilimlerinin çeşitli değişkenler açısından incelenmesi. Erzincan Üniversitesi Ë̆itim Fakültesi Dergisi, 18(1), 63-91.

Osman, K., Halim, L., \& Iksan, Z. (2003). The critical thinking attitudinal profile of some Malaysian secondary students: A reflection of scientific attitudes. Journal of Science and Mathematics Education in Southeast Asia, 26(2), 143-166.

Oxfam. (2015). Education for global citizenship. A guide for schools. United Kingdom: Oxfam. https://www.oxfam.org.uk/education/resources/education-for-global-citizenship-a-guidefor-schools (Erişim Tarihi 23.4.2020).

Özer, N. (2002). Kritik düşünme. Atatürk Üniversitesi Hemşirelik Yüksekokulu Dergisi, 5(2), 6377.

Paul, R., \& Elder, L. (2012). The thinkers guide to the nature and functions of critical and creative thinking. CA: The Foundation for Critical Thinking.

Paulus, P. B. 2000. Groups, teams, and creativity: The creative potential of idea generating groups. Applied Psychology, 49(2), 237-263.

Pike, G. (2008). Citizenship education in a global context. Brock Education Journal, 17(1), 3849.

Quinn, F. M. (2000). The principles and practice of nurse education. London: Stanley Thornes Ltd.

Ricketts, J. C. (2005). The Relationship between leadership development and critical thinking skills. Journal of Leadership Education, 4(2), 31-41.

Rudinow, J., Barry, V. E. (2008). Invitation to critical thinking. New York: Cangage Learning.

Şahin, M, Akbaşl1, S., \& Yanpar Yelken, T. (2010). Key competences for lifelong learning: The case of prospective teachers. Educational Research and Review, 5(10), 545-556.

Şahin, M., Şahin, S. ve Göğebakan Yıldız, D. (2016). Sosyal bilgiler eğitimi programı ve dünya vatandaşlığı: Öğretmen adaylarının perspektifinden. Hacettepe Üniversitesi Ĕgitim Fakültesi Dergisi, 31(2), 369-390.

Selvi, K. (2011). Teachers' lifelong learning competencies. Uluslararası Eğitim Programları ve Ögretim Dergisi, 1(1), 61-69.

Şenşekerci, E., ve Bilgin, A. (2008). Eleştirel düşünme ve öğretimi. Uludağ Üniversitesi FenEdebiyat Fakültesi Sosyal Bilimler Dergisi, 9(14), 15-43.

Stenfors Hayes, T., Griffiths, G., \& Ogunleye, J. (2008). Lifelong learning for all? Policies, barriers and practical reality for a disadvantaged group. International Journal of Lifelong Education, 27(6), 625-640. 
Ten Dam, G. \& Monique, V. (2004). Critical thinking as a citizenship competence: Teaching strategies. Learning and Instruction, 14, 359-379.

Toprak, M. ve Erdoğan, A. (2012). YBÖ: Kavram, politika, araçlar ve uygulama. Yükseköğretim ve Bilim Dergisi, 2(2), 69-91.

Torrance, E. P. (1968). Education and the creative potential. Minneapolis: The University of Minnesota Press.

Trilling, B. \& Fadel, C. (2009). 21st century skills: Learning for life in our times. Francisco: Jossey-Bass.

Ulupınar, S. (1997). Hemşirelik eğitiminin sorun çözme becerisine etkisi. (Yayımlanmamış Doktora Tezi). İstanbul Üniversitesi Sağlık Bilimleri Enstitüsü. İstanbul.

UNESCO (2014). Global citizenship education: Preparing learners for the challenges of the 21 st century. https://unesdoc.unesco.org/ark:/48223/pf0000265452 (Erişim: 23.4.2020).

Vardyan, A. \& Asadyan, Z. M. (Tarihsiz). What is critical thinking and its origin? http://www.ysu.am/files/textmama2.pdf (Erişim: 23.5.2020).

Yaman, F. ve Yazar, Y. (2015). Öğretmenlerin YBÖ eğilimlerinin incelenmesi (Diyarbakır ili örneği). Kastamonu Eğitim Dergisi, 23(4), 1553-1566.

Yeh, M. L. (1996). Translation and validation of the California critical thinking dispositions inventory Chinese. (Unpublished PhD Dissertation). University of Maryland. Baltimore.

\section{EXTENDED ABSTRACT}

Having a large number of critical thinking and active individuals is an important social feature for a society to preserve and develop its existence. This situation is among the leading issues of the last decades. The relationship of critical thinking with decision-making and science leads individuals to research and information, which increases the interest of individuals of all ages in learning. In other words, lifelong learning is inevitable for critical thinking activity. Critical thinking and lifelong learning are mentioned among the general characteristics of the global citizen individual, which is put forward as the necessity of the global world. Critical thinking is a high-level decision-making skill (Goryunova, Jenkins, 2017) Lipman (1988), on the other hand, defined critical thinking by attributing the concepts of reasoning, estimation, evaluation, preference, grouping, classification, logical inference, and hypothesis development. World citizenship refers to global awareness and active civic participation towards the functioning and problems of the world (Kronfli, 2011). According to Oxfam, people with a global citizenship identity should be knowledgeable on issues such as the shrinking of the world, "justice, equality and respect for diversity". In addition, world citizens should have skills such as critical thinking, effective discussion, cooperation and problem solving, empathy, self-respect and social justice (Kan, 2009b). "Lifelong learning is the continuous development of knowledge and skills that individuals experience mostly after formal education and throughout life" (Encarta Dictinoarry, 2008 cited in Lonra, 2011). Learning is about change and change has a directive feature. Adaptation is the keyword of change and development. In this respect, it is also related to the quality of life. Lifelong or continuous learning is generally seen as an adult or continuing education field (Lonra, 2011). When the studies were examined, it was determined that although the relations of these variables with different variables were examined, the relations of these three variables with each other were not examined. The research is unique in this respect. The findings of the study are expected to shed light on researchers and practitioners. The aim of the study is to examine the relationship between these three variables, while examining the prediction of lifelong learning and world citizenship perception on critical thinking. 


\section{Method}

In this study, a multi-factor predictive correlational design was used to examine the structural relationships between prospective teachers' lifelong learning, world citizenship efficacy perceptions and critical thinking dispositions. When there is only one predictor variable in the study, single factor predictive correlational design; When there are two or more predictive variables, multi-factor predictive correlational design is used (Büyüköztürk, Çakmak, Akgün, Karadeniz, Demirel, 2017; Fraenkel, Wallen, Hyun, 2012). In this study, lifelong learning disposition and world citizenship efficacy perception were determined as the predictor variables, while critical thinking disposition was determined as the predicted variable. The hypothetical model describing the relationships between these variables was tested through structural equation modeling. For the purpose of the research, 508 pre-service teachers from the departments of Turkish Language and Literature, Biology, Physics, Mathematics, History, Accounting, Philosophy, Sociology and Health, who attend pedagogical formation courses in two state universities, participated in the study. $65.4 \%(\mathrm{n}=332)$ of the students were female and $34.6 \%$ $(\mathrm{n}=176)$ were male. "California Critical Thinking Disposition Scale", "World Citizenship Competence Perception Scale" and "Lifelong Learning Tendency Scale" were used in data collection.

\section{Results}

In the study, there are 3 latent and 13 observed variables defined in the measurement model. In this part, the latent variable of critical thinking consists of the observed variables of analyticity, self-confidence, inquisitiveness, systematicity, the latent variable of lifelong learning consists of the variables of motivation, persistence, lack of regulating learning, and the latent variable of world citizenship consists of the observed variables of five items. A measurement with three latent and 13 observed variables was created and the compatibility of this measurement model with the data was tested. When the fit statistics of the measurement model were examined, it was determined that the chi-square was significant at the level of $\chi 2=233.203, \mathrm{sd}=61 \mathrm{p}=0.00$. The ratio between chi-square and degrees of freedom was calculated as $(\chi 2 / \mathrm{sd}=3,823)$. When the goodness of fit indices were calculated, $\mathrm{AGFI}=.906, \mathrm{GFI}=.937, \mathrm{CFI}=.919$, and RMSEA $=.075$ were obtained.

When the fit statistics of the structural model were examined, it was determined that the chi-square was significant at the $\chi 2=233.203, \mathrm{sd}=61 \mathrm{p}=0.00$ level. The ratio between chi-square and degrees of freedom was calculated as $(\chi 2 / \mathrm{sd}=3,823)$. When the goodness of fit indices were calculated, AGFI=.906, GFI=.937, CFI=.919 and RMSEA=.075 results were obtained. These values indicate that the model-data fit is acceptably good (Jöreskog, Sörbom, 1993; Marsh, Hocevar, 1988). The fit indices obtained in the model created as the independent critical thinking dependent variable of world citizenship and lifelong learning show that the model is within acceptable limits. As a result, both lifelong learning tendency and world citizenship perception predict critical thinking disposition.

\section{Conclusion}

Results of the study revealed moderate and low level significant relationships between critical thinking disposition, lifelong learning tendency and world citizenship perception. According to the final result of the research, the effects of lifelong learning and world citizenship on critical thinking were revealed in line with the views of pre-service teachers. Other variables that affect critical thinking can be examined. 